ELORE (ISSN 1456-3010), vol. 19 - 1/2012.

Julkaisija: Suomen Kansantietouden Tutkijain Seura ry.

[http://www.elore.fi/arkisto/1_12/salonsaari.pdf]

\title{
ArtikKeli
}

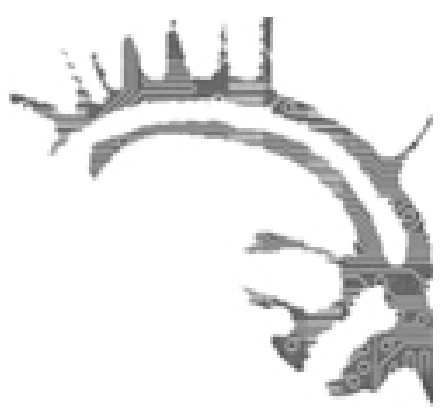

\section{KERROTTU JA MUISTELTU INKERINSUOMALAISTEN PALUUMUUTTO}

\author{
Minna-Liisa Salonsaari
}

\section{Paluumuuttajien Kertomuksia KuUlemassa}

Inkerinsuomalaisten ja muiden entisen Neuvostoliiton etniseltä taustaltaan suomalaisten paluumuutto on ainutlaatuinen osa Suomen historiaa. ${ }^{1}$ Paluumuutto alkoi vuonna 1990 ja on loppumassa paluumuuttojärjestelmää koskevan ulkomaalaislainmuutoksen astuttua voimaan heinäkuussa 2011. Paluumuuttojono sulkeutui ja viimeiset paluumuuttajat muuttavat Suomeen lähi vuosina. Inkeriläisiä paluumuuttajia ja heidän perheenjäseniään on tullut Suomeen kahden vuosikymmenen aikana noin $30000{ }^{2}$ Inkerin paluumuuttajat ovatkin Suomen suurin maahanmuuttajaryhmä.

Paluumuuton voi nähdä myös jatkumona vuosisataiselle muuttoliikkeiden virralle, joka alkoi viimeistään Stolbovan rauhasta vuonna 1617, jossa Ruotsi sai väliaikaisesti Inkerin haltuunsa. Tämän jälkeen suomalaisia, lähinnä savakkoja ja äyrämöisiä, muutti Inkerinmaalle. ${ }^{3}$ Suomalaisten muuttoliike Venäjälle jatkui tämänkin jälkeen, mutta suurimman suomalaisryhmän Venäjällä muodostavat Inkeriin muuttaneiden jälkeläiset, inkerinsuomalaiset. Juuri heitä suurin osa paluumuuttajistakin on.

Artikkelissani tarkastelen inkerinsuomalaisten paluumuuttoa muistitiedon ja kerronnan näkökulmista kahden inkerinsuomalaisen paluumuuttajanaisen haastattelukerronnan kautta. Aineistoani lukemalla pohdin, mitä kerrottu ja muisteltu paluumuutto on. Haastattelukerrontaa analysoimalla selvitän, millaisia kertomuksia paluumuutosta haastattelut ovat sekä miten paluumuutto tulee näiden kertomusten kautta esille. Ajatuksenani on, että kerronta ja muistitieto ovat merkityksellistä tietoa ja niiden tarkasteleminen tuottaa ainutkertaista tietoa paluumuutosta. Ajankohtaisena ilmiönä paluumuuton yksilötasoinen tarkasteleminen on erityisen mielenkiintoista ja tärkeää.

Tarkastelen kahden eri sukupolvea olevan inkerinsuomalaisen paluumuuttajanaisen, 
nuoren Annan ja eläkeikäisen Elsan, haastattelemisen tuottamaa kerrontaa. Haastattelut ovat osa vuosien 2010-2011 aikana Satakunnan alueella tekemistäni, yhteensä noin kymmenen paluumuuttajanaisen, haastatteluista. Anna muutti Suomeen Pietarista murrosiän kynnyksellä kymmenisen vuotta sitten. Hänen tarinansa on esimerkki kotoutumisesta osana kasvutarinaa. Elsa puolestaan oli asunut Suomessa vasta pari vuotta, mutta suomalaisuus ja suomalainen kulttuuri ovat olleet läsnä hänen elämässään aina. Inkerissä syntynyt Elsa onkin inkerinsuomalainen nainen. Näiden kertomusten kautta hahmotan, mitä Annan ja Elsan kerronnan tuottama kerrottu paluumuutto on ja mitä se pitää sisällään. Taustana tälle hahmotan aluksi inkerinsuomalaisten paluumuuton määrittelyjä. Keskityn artikkelissani inkerinsuomalaisiin, mutta ei sovi unohtaa, että entisen Neuvostoliiton alueen paluumuuttajien joukossa on myös muita etniseltä taustaltaan suomalaisia.

\section{INKERILÄISTEN PALUUMUUTTO}

Inkerinsuomalaisten paluumuutto-oikeus merkitsi sitä, että heidät määriteltiin ulkosuomalaisiksi. Ulkosuomalainen on ulkomailla asuva Suomen kansalainen tai suomalaista syntyperää oleva ulkomaan kansalainen, jolla on suomalainen identiteetti. Paluumuuttajan oletetaan olevan tietoinen suomalaisesta syntyperästään ja vaalivan syntyperäänsä liittyviä tapoja, perinteitä ja uskontoa. Hänen myös oletetaan osallistuvan ulkosuomalaisten kulttuuri- ja järjestötoimintaan, pitävän yhteyksiä Suomeen ja Suomessa asuviin, tuntevan Suomen olosuhteet, seuraavan Suomen tapahtumia sekä ylläpitävän suomen tai ruotsin kielen taitoa ja siirtävän sitä seuraaville sukupolville. (Inkerinsuomalaisten maahanmuutto Suomeen 1990-luvulla, 6-7.)

Inkerinsuomalaisten paluumuuton erottaa muusta Suomeen suuntautuvasta maahanmuutosta se, että siitä on säädetty erikseen Suomen ulkomaalaislaissa. Lainsäädäntö on kiristynyt vuosien varrella seuraten paluumuuttajien suomalaisuudesta käytyä keskustelua. Paluumuuton alkuvaiheessa pääkriteeri oli suomalainen "veren perintö". Vuoteen 1996 saakka riitti, että vähintään yksi isovanhemmista oli kansalaisuudeltaan suomalainen (Ulkomaalaislaki 22.2.1991/378, 18a』). Sen jälkeen vähintään kahden neljästä isovanhemmasta tuli olla merkitty suomalaiseksi luotettavaan asiakirjaan. Tässä vaiheessa lainsäädännöllisesti biologisen perimän rinnalle liitettiin ensimmäinen vaatimus suomalaisesta identiteetistä. Oleskeluluvan saamiseksi henkilöiden tulikin osallistua paluumuuttovalmennukseen lähtömaassaan, ellei pakottavaa estettä tälle ollut. (Laki ulkomaalaislain muuttamisesta 511/1996, 18a S.) Paluumuuttajan puoliso sekä hänen samassa taloudessa asuvat alle 18-vuotiaat lapsensa voivat myös saada oleskeluluvan. Vuoden 2004 ulkomaalaislaki (Ulkomaalaislaki 30.4.2004/301, 48』) jatkoi vuoden 2003 lakimuutoksen linjassa. ${ }^{4}$ Vuodesta 2003 lähtien paluumuuttoa haluavan on pitänyt osoittaa kielitaitonsa kielitestillä (Laki ulkomaalaislain muuttamisesta 218/2003, 18a ().

Inkerinsuomalaisten paluumuuton kehä on kuitenkin nyt sulkeutumassa, sillä paluumuutto-oikeus tulee päättymään lukuun ottamatta siirtoväkeen ja Suomen armeijaan kuuluneita inkeriläisiä. Paluumuuttojonoon ilmoittautuminen päättyi heinäkuun 
alussa 2011 ja mahdollisuus oleskelulupahakemusten jättöön heinäkuun 2016 alussa. (Laki ulkomaalaislain 48 5:n muuttamisesta 57/2011.) Viron osalta tilanne muuttui jo Viron liittyessä Euroopan Unioniin.

Paluumuuton ensimmäisiä vuosia jaotelleiden Pirjo Takalon ja Mari Juotteen mukaan ensimmäisessä vaiheessa paluumuuttajia tuli etenkin Virosta. Heidän suomen kielen taitonsa oli hyvä ja he työllistyivät nopeasti. Toisessa aallossa tulijoita oli erityisesti Inkerinmaalta ja Karjalasta. Heidän kielitaitonsa oli odotettua heikompi, mikä kavensi heidän mahdollisuuksiaan työmarkkinoilla laman lisäksi. Tässä vaiheessa Suomessa todettiin, että suomalainen syntyperä ei taannut valmiuksia suomalaisessa yhteiskunnassa toimimiselle. Monelta puuttui yhteiskunnallinen ja kulttuurinen tietous siitä, miten Suomessa eletään ja toimitaan. (Takalo \& Juote 1995, 53-56.) Paluumuutto jatkui tämän jälkeenkin. Suurin osa paluumuuttajista on tullut Suomeen nykyisen Venäjän alueelta, mutta myös muualta entisestä Neuvostoliitosta, erityisesti Virosta, on saapunut paluumuuttajia. Suomeen on muutettu sekä työn että sukulaisten perässä, mutta myös paremman elämän toivossa. Jokaisen muuton syy on yksilöllinen.

Arkipuheessa entisen Neuvostoliiton alueelta Suomeen tulevat paluumuuttajat yhdistyvät usein massaksi, jota nimitetään inkeriläisiksi paluumuuttajiksi, inkerinsuomalaisiksi paluumuuttajiksi tai inkerinsuomalaisiksi tai inkeriläisiksi. Suurin osa paluumuuttajista onkin nimenomaan inkerinsuomalaisia, mutta joukossa on myös muina aikoina alueelle muuttaneita. He kaikki muodostavat kansallisuudeltaan suomalaisten ryhmän, jolla on ollut mahdollisuus muuttaa tämän erityisen lain voimalla Suomeen. Sen lisäksi Suomeen on muuttanut myös Suomen kansalaisten jälkeläisiä, joiden isovanhemmat tai vanhemmat muuttivat Neuvostoliittoon. Heidän paluumuuttonsa poikkeaa lainsäädännöllisesti ja käytännössä etenkin siten, että heidän ei tarvitse inkerinsuomalaisten tavoin olla paluumuuttojonossa. Molempien paluumuuttajaryhmien kohdalla kyse on samankaltaisesta henkisestä prosessista, muutosta kulttuurista toiseen.

Kantasuomalaisten silmissä paluumuuttajat monesti sekoittuvat muihin Venäjältä tulleisiin maahanmuuttajiin, sillä heidän kulttuurinsa vaikuttaa Suomen suomalaisen silmiin venäläiseltä. Näkyvin tai kuuluvin kulttuurinen piirre on usein kieli, joka varsinkin nuoremman polven paluumuuttajilla yleensä on venäjä. Joskus paluumuuttajat yhdistetään myös virolaisiin, jos paluumuuttaja tulee Virosta ja on omaksunut viron kielen. Kaija Heikkinen on kirjoittanut paradoksista, joka syntyi, kun suomalaiset odottivat paluumuuttajien olevan suomalaisia mutta Suomeen tulikin venäläisiä. Suomessa yllätyttiin, kun osa paluumuuttajista olikin omaksunut venäläisen identiteetin ja kulttuurin. Paradoksin juuret Heikkinen ulottaa aina karelianismiin asti, jolloin suomalaisuus nähtiin tavoiteltavana ja venäläisyys vieraana ja rappiona. Osittain ongelmat johtuvat kriteereistä, joilla paluumuuttajat on määritelty. Pääkriteeri kun on "veren perintö", johon on liitetty vaatimus suomalaisesta identiteetistä - siitäkin huolimatta, että on tiedossa, että biologinen perimä ja kulttuuriperimä eivät korreloi keskenään. (Heikkinen 2003, 158-163.)

Moni haastateltavistani on todennut olevansa paluumuuttaja. Usein haastateltava toteaa tämän kuin ohimennen, ulkopuolisella äänensävyllä. Määritelmä onkin jotain, mikä tulee ulkoapäin eikä välttämättä kumpua henkilön omasta identiteetistä. Paluumuuttaja-käsitteen ohella myös ilmaisu inkerinsuomalainen on syntynyt lähinnä Suomen suomalaisten lähtökohdista, keinoksi erottaa Suomen suomalaiset ja Inkerin 
suomalaiset. Kansallisuudeltaan he ovat suomalaisia ja suomalaisiksi heitä on Venäjällä ja Neuvostoliitossa kutsuttu. Toisinaan synonyymin kaltaisesti käytetään sanaa inkeriläinen, jolla kuitenkin voidaan tarkoittaa kaikkia Inkerissä asuneita tai asuvia eli inkerinsuomalaisten ohella erityisesti vatjoja ja inkerikkoja.

\section{KERROTTUA PALUUMUUTTOA TAVOITTAMASSA}

Artikkelissani tarkastelen paluumuuttoa kerrottuna paluumuuttona eli sellaisena kuin inkerinsuomalaiset paluumuuttajat asian haastattelupuheessa esittävät. Paluumuuton tai ylipäätään maahanmuuton kerrontaa ei kuitenkaan ole vain muuttajien kerronta. Sitä ovat myös kantaväestön esittämät kertomukset aiheesta. Aihetta kuvaavat myös erilaiset oppaat ja akateemiset tutkimukset. Esimerkiksi Pirjo Takalon ja Mari Juoteen vuonna 1995 julkaisema Inkerinsuomalaiset -teos on toiminut monen paluumuuttajien kanssa työskentelevän "oppaana" inkerinsuomalaisiin. Vuonna 1992 ilmestynyt kokoomateos Inkeri - Historia, kansa, kulttuuri (Nevalainen \& Sihvo toim.) puolestaan on avain Inkerin historiasta kiinnostuneille.

Kerrottu paluumuntto on oma käsitteeni, jolla tarkoitan paluumuuttokokemuksen esittämistä kertomuksen avulla. Kertomus on Matti Hyvärisen mukaan tietämisen muoto ja ihmisten välistä kommunikaatiota. Kertomus on vuorovaikutuksen väline, sillä kertomalla jaetaan ja tehdään ymmärrettäväksi kokemuksia, luodaan luottamusta ja ylläpidetään ryhmiä. Kertomuksella vastataan kysymykseen kuka minä olen. (Ks. esim. Hyvärinen 2006, 1.) Kerrottu paluumuutto onkin paluumuuttokokemuksen rakentumista kertomukseksi. Kyseessä on henkilökohtainen vuorovaikutuksellinen kuvaus oman elämän ja yksilön osasta.

Löysin kerrotun paluumuuton haastatellessani vuosien 2010 ja 2011 aikana väitöskirjatutkimustani varten kymmenkuntaa Satakunnan alueelle entisen Neuvostoliiton alueelta tullutta paluumuuttajaa, joista suurin osa oli inkerinsuomalaisia. Haastattelutilanteissa syntyi haastattelupuhetta, joka on haastattelutilanteen vuorovaikutuksessa syntynyttä suullista kerrontaa. Artikkelissani tarkastelen kahden haastateltavani, Annan ja Elsan, kerrontaa keskittyen ennen kaikkea siihen, mitä haastateltavani ovat minulle kertoneet. Nämä kertomukset ovat minulle väylä tavoittaa kokijoiden omaa kokemusta paluumuutosta. Tarkasteluni keskittyy kertomusten sisältöön eli siihen, mitä haastateltavani kertovat omasta paluumuutostaan.

Haastattelujen tuottama kerronta on muistitietoa. Tutkimuksessani muistitieto on keino tarkastella aihetta paluumuuttajien omista näkökulmista käsin. Puhujan subjektiivisuus on tällöin ainutlaatuinen ja arvokas elementti. Nämä lähteet eivät kerro ainoastaan, mitä ihmiset tekivät, vaan sen mitä he halusivat tehdä, mitä he uskoivat tekevänsä ja mitä he jälkikäteen katsovat tehneensä. (Portelli 2006, 55.) Jokainen paluumuuttajan kertomus on syntynyt yksilöllisistä kokemuksista yksilöllisissä tilanteissa. Jokaisella paluumuuttajalla on omat lähtökohtansa paluumuutolle sekä omat yksilölliset kokemistapansa ja syynsä kertoa asiasta niin kuin he kertovat.

Paluumuuttajahaastateltavien tavoittaminen osoittautui yllättävän haasteelliseksi. Satakunnassa ei toimi inkerinsuomalaisten omaa yhdistystä. Tavoitin monen haastatel- 
tavani, kuten esimerkiksi Elsan, Porissa toimivan Satakunnan monikulttuuriyhdistyksen välityksellä. Vierailin muun muassa Satakunnan monikulttuuriyhdistyksen tapahtumissa, joihin tiesin paluumuuttajia osallistuvan. Niistä tavoittamani paluumuuttajat edustivat etenkin vanhempaa sukupolvea. Osan haastateltavistani tavoitin sattumalta ja lumipallotaktiikkaa käyttäen. Eräästä haastateltavastani kuulin tutkijakollegaltani, erään löysin luennoimasta inkerinsuomalaisuudesta.

Haastateltavakseni päätyneet naiset suostuivat mielellään kertojikseni. Heidän lisäksi tapasin muitakin inkerinsuomalaisia: kaikki eivät olleet halukkaita haastateltavaksi tai jopa välttelivät aihetta. Tiedostamattomasti olen päätynyt haastattelemaan ainoastaan naisia, siksi myös tämä artikkeli tuo esiin ainoastaan naispaluumuuttajien kerrontaa. Miespuolisia paluumuuttajia en käyttämilläni menetelmin onnistunut tavoittamaan. Heitä ei vierailemistani tapahtumista löytynyt tai lumipalloillani tavoittanut. Sukupuolta tärkeämpää artikkelissani kuitenkin on kahden erilaisen, eri sukupolveen kuuluvan yksilön kerronta.

Satakunnassa tai Porissa paluumuuttajia ei ole paljon, mutta suhteellisesti kyse on kuitenkin mittavasta ilmiöstä. Muun Suomen tavoin paluumuuttajat ovat Satakunnassakin alueen suurin maahanmuuttajaryhmä. Porissa oli vuonna 2000, kun kaupunki julkaisi maahanmuuttajien kotouttamisohjelman, noin 650 ulkomaan kansalaista, joista noin 290 oli inkeriläisiä paluumuuttajia. Venäjää äidinkielenään puhui tuolloin 330 ja viroa 80 henkilöä. (Porin kaupungin Maahanmuuttajien kotouttamisohjelma, 2000.) Vastaavasti koko Satakunnan alueella venäjää äidinkielenään puhuvia oli 435 henkilöä vuonna 1995, 764 henkilöä vuonna 2000 ja 1042 henkilöä vuonna 2010 (Suomen virallinen tilasto (SVT), Väestörakenne). Tilastointitavasta johtuen paluumuuttajien kokonaislukumäärää ei ole saatavissa. Voikin sanoa paluumuuttajien katoavan tilastoihin erityisesti sen jälkeen, kun he ovat saaneet Suomen kansalaisuuden. Poriin on muuttanut paluumuuttajia 2000-luvullakin, vaikkakin tosin vähenevässä määrin. Esimerkiksi vuonna 2007 Poriin saapui 4 paluumuuttajaa entisen Neuvostoliiton alueelta (Paluumuutto entisen Neuvostoliiton alueelta vuosina 2000-2007), kun vielä vuonna 1999 muuttajia oli 42 henkilöä. (Paluumuutto entisen Neuvostoliiton alueelta 1998 ja 1999).

Paluumuuttajamäärän pienuudesta johtuen olen pyrkinyt tekstissäni välttämään paljastamasta liikaa haastateltavieni henkilöllisyydestä. Haasteltavieni omasta toiveesta nimitän heitä tutkimuksessani oikeilla etunimillään. Näin he kokivat voivansa tuoda oman tarinansa kuuluville. Sen sijaan vältän mainitsemasta haastateltavieni tarkkaa ikää, asuinkuntaa sekä paluumuuttovuotta. Haastateltavani ovat kirjallisesti suostuneet haastattelujen käyttöön tutkimuksessani.

Jokainen tekemäni haastattelu osoittautui erityiseksi. Haastattelu on alkanut siitä, että olen pyytänyt haastateltavaa kertomaan, kuka hän on. Tästä on lähtenyt usein liikkeelle polveileva elämäkerta, jossa paitsi paluumuutto, mutta myös kertojan varhaisempi elämä on rakentunut kertomukseksi. Paluumuuttoa edeltävä aika on tällöin toiminut paluumuuton kontekstin rakentajana. Haastattelun kuluessa olen esittänyt täsmentäviä kysymyksiä tai pyytänyt haastateltavaa kertomaan jostain paluumuuttoon liittyvästä asiasta omien kokemustensa kautta. Haastattelija johdattaa aina vähintään jossain määrin kerronnan kulkua. Haastateltavat ovat tienneet, kuka minä olen ja 
mitä tutkin. Kertomukset rakentuvat aina vuorovaikutuksessa, jonka vaikuttajina ovat vähintään kertoja ja kuulija tai lukija. (Ks. esim. Makkonen 2009, 39-41.)

Minun ja haastateltavani välisissä haastattelutilanteissa rakentui sanalliseen muotoon kertojien henkilökohtaisia kokemuksia, asioita, jotka kertojalle ovat tärkeitä. Haastattelujen sisältöön ja ennen kaikkea rakenteeseen vaikuttaa eittämättä se, että tein haastattelut suomeksi. Elsalle suomi oli äidinkieli, joka oli päässyt ruostumaan venäjän ollessa hallitseva kieli. Annan äidinkieli oli venäjä, suomea hän oppi oikeastaan vasta Suomeen muuttonsa jälkeen. Anna totesikin kielen toisinaan aiheuttavan hänelle yhä ongelmia: jotkin asiat voisi imaista paremmin ja syvällisemmin omalla äidinkielellään.

Paluumuuttajien haastatteleminen tuotti elämäntarinoiden palasia sekä kertomuksia inkerinsuomalaisten paluumuutosta paluumuuttajien silmin. Nämä kertomukset muotoutuivat haastattelutilanteessa pätkittäin tai haastattelu koostui enemmänkin useasta kertomuksesta. Jokainen inkerinsuomalainen paluumuuttaja on yksilö, jolla on yksilöllinen taustansa, joten myös jokainen haastattelutilanne ja jokainen kertomus on yksilöllinen. Entisen Neuvostoliiton alueen paluumuuttajista puhuttaessa erilaisten taustojen määrä laajenee erilaisiin maantieteellisiin paikkoihin ja erilaisiin yhteisöihin hajaantumisen myötä. Siksi on olemassa myös kulttuuriltaan ja kulttuuriperinnöltään erilaisia paluumuuttajia.

Haastatteluaineistosta on nähtävissä sekä kerrontatapoja että mikä on haastateltavalle kertomisen arvoista (ks. esim. Ukkonen 2000, 39-40, 63-65, 110-113). Paluumuuttoon liittyvän kerronnan tallettaminen on tärkeää sillä pian päättyvä paluumuutto entisiltä Neuvostoliiton alueilta on ollut Suomelle merkittävä ilmiö. Onkin mielenkiintoista pohtia, miten käy kerrotun paluumuuton, kun paluumuutto päättyy? Muodostuuko paluumuuttajille tietynlainen kerrontaperinne?

Samalla, kun paluumuuttajien haastatteluaineisto pitää sisällään yksilön elämäntarinan osia, se kertoo myös paluumuuton osalta sopeutumisesta Suomeen. Tekemissäni haastatteluissa olen keskittynyt kuuntelemaan laajemmin paluumuuttajien elämäntarinoita, tai niiden osasia, sillä pelkän sopeutumiskysymyksen kuunteleminen voisi jättää jotain olennaista kuulematta. Sopeutuminen tapahtuu osana muuta elämää, joten sopeutumisesta kertoo myös muu kuin suora sopeutumiskerronta.

Tutkijalle avautuu helposti ainoastaan niin sanotun hyvän maahanmuuttajuuden kuva. Esimerkiksi syrjäytyneiden paluumuuttajien tavoittaminen on vaikeaa. Haastatteluun tavoittamani ihmiset ovat kertoneet minulle kaiken olevan hyvin. Mikäli ongelmia on ollut, ne kuvataan menneisyytenä mistä on selvitty. Voisi ajatella, että haastattelut noudattavat paluumuuttajuuden mallitarinaa eli yhteisössä yleisesti tunnettua tarinaa, johon kertoja suhteuttaa oman tarinansa (ks. esim. Hänninen 1999, 50-52; Ukkonen 2007, 12-14).

\section{ANNAN KOTOUTUMIS- JA KASVUTARINA}

Suomeen muutin kakstoistavuotta sitten yhtenä päivänä vaan, hups.

Annan kotoutumiskertomus, josta yllä oleva ote on pieni yksityiskohta, on samalla kertomus hänen kasvustaan murrosikäisestä aikuiseksi. Anna muutti Suomeen van- 
hempiensa mukana kaksitoistavuotiaana. Suomessa asumiensa yli kymmenen vuoden aikana hänen ei ole ainoastaan tarvinnut kotoutua uuteen asuinmaahansa, vaan myös kasvaa aikuiseksi ja löytää oma paikkansa maailmassa. Muutto Suomeen merkitsi Annalle tulevaisuuden suunnitelmien, jotka siihen asti olivat liittyneet Pietariin, uudelleen miettimistä. Muutto ei ollut vain muutto vieraaseen paikkaan vaan myös vieraaseen tulevaisuuteen:

Eli ei mulle paljon tämmösestä, että muistan vaan että pari päivää ennen sitä ko tultiin tänne, vanhempani sanoivat et, no niin alapas pakkaamaan sun tavaroita, et mennään Suomeen. Mut ei se silleen, koska just varmaan sen takia et oli paljon koulua, sit muita harrastuksia. Et ei siinä ehtinyt perehtyä koko asiaan. Eikä ees niin ku ajatelut, et nyt muutetaan jonnekin pysyvästi asumaan. Et hoksasin sen asian vasta täällä. Oli kauhee paniikki et. Tajusin sen, että muutettiin niin kun tänne pysyväks, vasta täällä. Mikä oli aika iso shokki.

Anna kertoi, että eräänä päivänä hänen vanhempansa ilmoittivat perheen muuttavan Suomeen. Varsinaisesta paluumuuttoprosessista hänellä ei ole muistikuvia, sillä oikeastaan vasta silloin, kun perhe oli asettunut Suomeen, hän tajusi elämänmuutoksen olevan lopullinen. Hän kertoi tilanteen olleen järkytys. Hän mainitsikin itkeneensä ensimmäisen vuoden aikana paljon. Suomalainen kaupunki oli vieras ja elämä siellä alkoi vailla ainuttakaan tuttavaa. Asuinpaikka oli valittu asunnon saatavuuden sekä meren läheisyyden perusteella. Muualla Suomessa asui kuitenkin tuttuja ja sukulaisia. Samassa kerrostalossa asui muita venäjänkielisiä, jotka pidempään Suomessa asuneina osasivat auttaa käytännön asioissa.

Ennen perheen Suomeen muuttoa Annan vanhemmat olivat käyneet Suomessa pari kertaa, mutta Anna ei tuntenut maata lainkaan. Aivan kaikki ei kuitenkaan ollut vierasta. Jonkinlainen yhteys Suomeen oli muodostunut Suomessa asuvien sukulaisten kertomusten kautta. Hän tiesi, "että meil on siellä sukulaisia, jotka toivat meille ihania Fazerin suklaita ja kaikkee tommosta". Suomalainen kulttuuri oli Pietarissa varttuneelle inkerinsuomalaiselle tuttua, sillä asuuhan Pietariin alueella melko paljon inkerinsuomalaisia ja muita suomalaisia. Perinteiseen inkerinsuomalaiseen tapaan Annan perhe on evankelisluterilainen ja Pietarissakin he viettivät esimerkiksi joulua luterilaisten tapojen mukaisesti. Suomi on hänen vanhempiensa äidinkieli, mutta Annan oma suomenkielen taito ei ollut yhtä hyvä, vaikka hän olikin opiskellut jonkin verran suomea koulussa. Annan äidinkieli on venäjä. Se oli pääasiallinen kieli myös koulussa ja arjessa.

Anna jakoi itse oma-aloitteisesti sopeutumisensa periodeibin, kuten hän itse asian ilmaisi. Nämä ajanjaksot perustuivat kotoutumisen- ja elämänvaiheisiin. Koska hän puhui kotoutumisestaan hyvin jäsennellysti, kysyin häneltä haastattelun lopuksi, kuinka paljon hän on Suomeen muuttoaan ja kotoutumistaan pohtinut. Anna vastasi näin:

Mä oon fatalisti eli mä uskon siihen, kun jotakin tapahtuu niin sen on tapahduttava. Et turha miettiä, et joo oli tommosia aikoja ja tommosia. 
En haluais et ne, tai siis et ne tulis mieleen, mut en haluis enää pohtia niitä niin. Koska turhaanhan sä kattot taakseppäin, koska sä käännät sun selkäs tulevaisuudelle. Et niitä on vähän turha pohtia. Sen enempää. En tiedä. Siis kyl mä niitä jonkin verran pohdin ja kyllä me kavereiden kaa joskus puhutaa siitä kotouttamisest ja ylipäätänsä mutta. Se on elämää. Ja elämä on.

Asioiden läpikäyminen oli ollut enemmän ehkä tiedostamatonta. Muutto ja kotoutuminen ovat olleet osa Annan elämää. Hän kertoi uskovansa kaiken tapahtuvan syystä. Nyt hän haluaa katsoa tulevaisuuteen. Se on Annan kotoutumisstrategia.

Ensimmäistä Suomessa viettämäänsä ajanjaksoa Anna hahmotti koulunkäynnin ja suomen kielen oppimisen kautta. Nämä ensimmäiset vuodet Suomessa olivat myös hänen viimeiset peruskouluvuotensa. Anna kertoi tunteneensa itsensä eksyneeksi sekä olleensa kapinallinen ja negatiivinen. Hän kertoi, että ei oikeastaan edes halunnut kotoutua, sillä hän halusi ainoastaan muuttaa takaisin Venäjälle. Outo suomen kieli teki koulunkäynnistä vaikeaa.

Se oli aika vaikee se periodi. Ylipäätänsä koko yläaste aika. Mä osasin kieltä jo jonkin verran ja sit lukios sai puhua enemmän ja. Et ei ollu... Siis se kapinallisuus lähti eli aikuistuin pikkusen. Niin. Se oli jo suht hyvä periodi. Eli aloin kotiutua. Sulkumerkeis.

Lukion aloittaminen merkitsi Annan kertomuksessa uutta kotoutumisajanjaksoa. Hän oli oppinut suomen kielen, mikä helpotti koulunkäyntiä. Kaikkea ei tarvinnut läksyjä tehdessä kääntää sanasta sanaan. Anna ajoitti aikuistumisensa ja kotoutumisen alun samaan vaiheeseen. Kotoutumisen alkamisen hän sanoo kuitenkin tapahtuneen "sulkumerkeis", sillä hän koki varsinaisen sopeutumisen tapahtuneen vasta muutaman vuoden kuluttua. Kolmas ajanjakso hänen kertomuksessaan alkoi ammattikorkeakouluopintojen aloittamisesta ja muutosta toiseen kaupunkiin.

Mut toi korkeakoulu se oli tosi hyvä koska. Eli seittemän vuoden jälkeen. - - Eli silloin kotiuduin. - - Ensimmäiset kymmenen vuotta on vaikeita ja sit helpottaa. Ainakin mun tapauksessa oli näin.

Anna arvioi kerronnassaan, että murrosikä on ihmiselle vaikein ikä muuttaa uuteen kulttuuriin ja maahan. Hän näki, että pienten lasten on helpompi sopeutua, ja aikuiset puolestaan muuttavat omasta tahdostaan. Kaikesta huolimatta Anna ei eristäytynyt. Hän aloitti harrastukset pian Suomeen muutettuaan ja tutustui niiden kautta uusiin ihmisiin. Hän osallistui myös Satakunnan monikulttuuriyhdistyksen toimintaan, kun se aloitti toimintansa Porissa. Hän uskookin yhdistyksestä olleen myöhemmin muuttaneille paljon apua.

Anna kertoi minulle myös kotoutumisstrategioistaan. Hän painotti, että jokainen maahanmuuttaja kotoutuu omalla tavallaan. Hän arveli olevansa nyt jo riittävän kotoutunut. Sopeutumisessa suuri merkitys on ollut kavereilla sekä ennen kaikkea kielen oppimisella. 
Mut sit ehkä varmaan myös se et ku on oppinut kieltä. Eli pystyy kattomaan televisiota, kuuntelemaan musiikkia. Ja sit. Just se kielen ymmärtäminen. Siitä on tullut tosi hyvä apukeino.

Keskustelimme haastattelun yhteydessä lisäksi siitä, mikä kotoutumisessa on ollut vaikeaa. Anna kuvaili, että hänelle vaikeinta oli ulkopuolisuuden tunne - siitä huolimatta, että kokee sopeutuneensa. Suomalaisten erilaiseen mentaliteettiin on myös ollut vaikea tottua. Anna muotoili asian näin:

Varmaan sen ymmärtäminen. Varmaan kummiskin tajuat et, että, et olet täällä ihan niin ku kotona. Ja joskus siitä muistutetaan. Että et aina kuulu tähän yhteiskuntaan. Se varmaan. Ja sit. No ehkä se kun se mentaliteetti on kuitenkin erilainen. Mihin mä oon siis. En voi sanoa, ett tottunu mut. Koska Venäjän mentaliteetti ja Suomen mentaliteetti, on kummiskin pikkasen erilaisia. Et. Jos mä vaikka. No sekin riippuu ihmisest ja kaupungist mis asuu. Helsingis on ihan normaalia jos sä meet puhuun jollekkin. Et sua ei katota, et joo mitäs sä multa haluut. Mut ehkä taas jossakin niin ku pienemmäs kaupunkis jossa ei oo. Jos ei oo niin ku tapa ihmiset puhuvat. Niin. Tai en mä tie. Semmonen. Yym. Eli varmaan semmonen et ihmiset eivät tuntuneet niin avoimelta kuin vaikka venäläiset. Eli varmaan sen takia. Mut sekin riippuu ihmisestä. Et mul on montakin suomalaista, hyvää suomalaista kaveria. Jotka ovat niin ku kymmenen kertaa avoimempia, kun vaikka venäläinen. Tai se varmaan mihin törmää. Joiden kanssa on yhteydessä.

Anna kertoi, että hän pitää mentaliteettiaan venäläisenä. Hän kertoi kokevansa itsensä 60 \%:seksi venäläiseksi. Suomessa hän usein kokee olevansa venäläinen, mutta toisaalta taas Venäjällä suomalainen: "Mä oon venäläinen, jol on suomalaiset juuret." Juurien Inkeri on Annalle myyttinen paikka. Hän kertoi, että ei kovinkaan paljon tiedä Inkeristä, mutta voi olla, että haluaa jonain päivänä oppia siitä lisää. Suomalaisuus on kunnioitusta isovanhempia kohtaan.

Mutta suomalaiseks se, et totta kai mä kunnioitan mun isovanhempien perintöä, juurta, koska ne oikeesti olivat suomalaisia suomalaisia tai inkeriläisiä. Puhuivat suomea ja muutenkin. Mutta. Se mun näkemys omasta ittestäni vähän niin ku laimennettua et se oli jossakin. Et ei mulla oo semmost vahvaa, joo et mä oon suomalainen tai mä oon venäläinen.

Anna käy Venäjällä yhä säännöllisesti pari kolme kertaa vuodessa. Ystäviinsä Venäjällä hän pitää yhteyttä esimerkiksi Skypellä. Venäjä ja venäläisyys ovat siis Suomeen kotoutumisesta huolimatta iso osa hänen elämäänsä edelleen. 


\section{ELSA, INKERINSUOMALAINEN NAINEN}

Suomessa otettiin hyvin ja minulla on tuota hyvä asunto. Minä asun tuolla --. Ja kaikki on kaunista ja hyvää. Minusta kaikki miellyttää. Minä olen tyytyväinen.

Inkerissä ennen toista maailmansotaa syntyneen Elsan paluumuuttokertomus nivoutuu osaksi inkerinsuomalaisen naisen elämänkaarta. Haastatteluhetkellä, josta yllä oleva lainaus on, Elsa oli asunut Suomessa vasta kaksi vuotta, mutta painotti useaan otteeseen sopeutumistaan. Hänen äidinkielensä on suomi, ja hänen kotinsa tavat olivat (inkerin)suomalaisia. Lapsuuden kodissa puhuttiin aina vain suomea, venäjää perheen äiti ei edes kunnolla osannut. Eläkkeelle jäätyään Elsa päätti muuttaa Suomeen, missä hänen lapsensa jo asuivat.

Siinä missä Anna keskittyi paluumuuttoonsa ja sen kokemiseen, oli Elsan kerronnassa paluumuutto vain yksi, lyhyehkökin, vaihe elämästä. Minulle jäi tunne, että hän olisi mieluiten kertonut varhaisemmista elämänvaiheistaan ja inkerinsuomalaisten vaiheista ylipäätään. Varsinaisen haastattelutilanteen päätyttyä hän jatkoikin omasta elämästään kertomista. Inkerinsuomalaisen muistin säilyttäminen on Elsalle tärkeää, mitä osoitti esimerkiksi se, että hän toi minulle veljensä inkerinsuomalaisten vaiheita käsitteleviä kirjoituksia.

Suomi oli Elsalle tuttu jo ennen Suomeen muuttoa. Lukuisien muiden inkerinsuomalaisten tavoin Elsan perhe oli siirretty Suomeen sotien aikana. Rauhanteon jälkeen he, kuten valtaosa Inkerin siirtoväestä, palasivat Neuvostoliittoon. Kotiseudulle Inkeriin he eivät kuitenkaan päässeet, vaan heidän tiensä vei Novgorodiin. Erinäisten vaiheiden kautta Elsa päätyi Petroskoihin, jossa hän on asunut suurimman osan elämästään.

Karjala meit otti vastaan. No Petroskoissa tietysti silloin oli kaikki suomen kielellä. Radio ja sanomalehet ja kaikki suomen kielellä. Ennen. Ennen. Mutta nyt kaikki on muuttunut. No suomen kielellä on vielä tuota ja suomen teatteri on vielä. Mutta kaikki näyttelijät on, melkein kaikki näyttelijät tulleet tänne Suomeen.

Petroskoissa oli paljon suomenkielisiä sekä suomenkielistä kulttuurielämää. Kielen ja suomalaisen kulttuurielämän vankkaa asemaa Petroskoissa Elsa kuvaa menneenä aikana. Se on mennyttä paitsi hänen elämässään, mutta myös yleisemmin, sillä monet kaupungin kulttuurihenkilöistä ovat muuttaneet Suomeen paluumuuton tultua mahdolliseksi.

Suhteellisen hyvästä kielitaidosta huolimatta Elsa on Suomeen muuttonsa jälkeen käynyt säännöllisesti suomen kielen tunneilla. Hän korosti, että haluaa puhua suomea oikein, ja pahoitteli useaan otteeseen puheessaan tekemiään virheitä. Kieliopinnoissa Elsa kertoo tapaavansa myös muita samassa tilanteessa olevia ystäviään.

Ihan ensimmäisestä päivästä, kun muutin tänne. Ja tänne kielen kurssia. 
Ja pitää, että tuota ainakin oikeen ettei tee virheitä. Pitää puhua Suomea. Joo käyn. En ole yhtäkään oppituntia laskenut. Aina käyn.

Elsa totesi, että asuinkaupunkinsa Porin murre tuottaa hänelle joskus vaikeuksia. Kuuluvathan Porin murre ja Inkerin murre eri murrealueisiin. Itäsuomalaisia onkin Elsan mukaan paljon helpompi ymmärtää.

Minun naapurikin. Hän on ihan porilainen kantaperält. Hänen kans on puhua paljon vaikeampi. Kun sieltä Pohjos-Suomesta Kajaanista ja tuota Kuhmosta. Se on niin ku Suomen Karjala. Ja se kieli on oikeen lähellä meidän kieli. Ja niin on helppo heiän kanssa. Joo, mutta Porinki kieli on vähän erilainen. Joo, murre, murre.

Suomi oli Elsalle tuttu myös useilta matkoilta sekä suomalaisten ystävien kautta. Hän kertoi, että mikään ei tullut Suomessa suurena yllätyksenä, sillä suomalainen elämäntapa oli hänelle etukäteen tuttua. Elsa kertoi kaiken olevan Suomessa hyvin ja viihtyvänsä maassa. Hän kertoi entisten työkavereiden Petroskoista ihmetelleen, miten Elsa jakselee Suomessa. Heille hän on kertonut voivansa hyvin.

Ja kaikki on kaunista ja hyvää. Minusta kaikki miellyttää. Minä olen tyytyväinen. Kaikki rauhallista. Minä olen kovin iloinen. Rauhallista. Ja naapurit rauhallisia. Kaikki on kaunista ja puhdasta. Saa mennä ulkona kävelylle vaik yöllä. Ei peloita. Suomessa tietyst kaikki on niin kaunista ja hoidettua. Ei missään ole roskaa. No kaikki on normaalia. Kaikki hyvin. Minä olen kovin tyytyväinen.

Elsan paluumuuttokertomus on kuvaus hänen eläkeiästään, sillä hän muutti Suomeen vasta eläkkeelle jäädessään. Paluumuutto kiinnittyykin tähän elämänvaiheeseen ja -muutokseen. Elsa on kertomansa perusteella aktiivinen eläkeläinen. Hänellä on paljon ystäviä ja harrastuksia: "Vaikka on korkea ikä, mutta tuota, minä olen semmonen, että en istu kotona." Satakunnan monikulttuuriyhdistyksessä hän käy kielitunneilla ja osallistuu moniin rientoihin. Hän käy martoissa, teatterissa ja pitää lukemisesta.

Inkerinsuomalaiseen kulttuuriin on vahvasti liitetty evankelisluterilainen uskonto. Elsakin tuo tätä piirrettä esiin jäsentäessään elämäntarinaansa. Inkeri on paikka, jossa hän syntyi. Rippikoulun hän kävi Petroskoissa. Hän myös mainitsee olevansa kirkon jäsen. Kun hän täytti 70 vuotta, merkkipäivää juhlittiin kirkossa. Uskonto merkitseekin hänelle vanhemmilta saatua kulttuuriperintöä. Hänen muistoissaan on, kuinka hän vanhempiensa kanssa kuunteli Venäjällä sinne kantautuneesta Suomen radiosta aamuhartauden ja sunnuntaina jumalanpalveluksen. Samalla hän kertoo kuunnelleensa sukupolvensa suomalaislasten tavoin Markus-setää. Radionkuunteluhetkien kautta uskonto limittyy perheen yhteisiin hetkiin.

Meidän perhe oli usko. Isä ja äiti kovin uskovallisia. Ja koska pienenä minä 
olin Venäjällä radiossa aina kuuntelivat aamuhartauden. - - Ja jumalanpalvelusta sunnuntaina. Ain joka sunnutai istuin äidin ja isän rinnalla ja lauloin virsikirjasta.

Siinä, missä nuori Anna kertoi mentaliteettinsa olevan venäläinen, sanoi Elsa painokkaasti, että ei ole koskaan kokenut olevansa venäläinen. Tästä todistuksena hän kertoi yhä tallessa olevasta Neuvostoliiton passistaan, jossa hänen kansallisuudekseen on merkitty suomalainen. Suomalaisuus on märitellyt hänen elämänsä kulkua. Suomalaisuutensa vuoksi heidän perheensä siirrettiin sodan aikana monien muiden inkeriläisten tavoin Suomeen. Suomalaisuutensa vuoksi he eivät päässeet Neuvostoliittoon palattuaankaan asumaan kotiseudulleen Inkeriin. Elsa pitää edelleen yhteyttä Venäjällä asuviin ystäviinsä ja sukulaisiinsa. Hän on myös vieraillut Venäjällä sisarustensa luona sekä käynyt vanhempiensa haudalla.

Minusta vaikutti siltä, että Elsalle oli hyvin tärkeää kertoa minulle, kuinka hyvin hänen lapsensa ja lapsenlapsensa ovat tulleet toimeen Suomessa ja että he eivät ole suomalaisten taakkana. Kaikki he tekevät töitä ja opiskelevat. Kukaan ei ole työttömänä.

Minä joskus sanon pojalleni, että minä viel sen vuoksi Suomeen, miten minä olen koko elämäni Venäjälle tehnyt neljäkymmentä vuotta töitä, ja minä mänen Suomeen suomalaisen harteille. Niin hän sanoo että tuota sano äiti, ei se sinuu koske sen vuoksi, että me käyvään kaikki töissä. Me maksetaan verot. Joo. Et sinä vaan riipu siinä, että suomalaiset maksavat.

\section{ERILAISIA PALUUMUUTTOKERTOMUKSIA}

Annan ja Elsan kertomukset ovat kahden eri sukupolveen kuuluvan naisen kertomuksia. Erilaiset sukupolvet ja erilaiset elämänkokemukset tuottavat erilaisia kertomuksia. Esimerkiksi vanhemmalle polvelle inkerinsuomalaisten kärsimyshistoria on henkilökohtaista menneisyyttä. Nuoremmille samat kertomukset ovat yhteisön historiaa. Osalle oman yhteisön tai suvun historia ja tarinat voivat olla hyvin etäisiäkin, koska asioista on vaiettu. Paluumuutto limittyy kertomuksissa henkilökohtaisiin elämänvaiheisiin - Annalla lapsesta aikuiseksi kasvamiseen ja Elsalla eläkeikään. Henkilökohtaisuudessaan nämä paluumuuttajien kertomukset tuovat esiin sen, että on olemassa erilaisia paluumuuttoja, erilaisia paluumuuttokokemuksia sekä erilaisia tapoja kertoa paluumuutosta ja sen kokemisesta. Kerronta sekä selittää että myös rakentaa inkeriläisiä identiteettejä ja kulttuuriperintöä. Kaikki aiheesta kerrottu, kuvattu ja esitetty ovat vaikuttaneet niihin märittelytapoihin, joilla paluumuuttajat itse määrittelevät itseään, mutta myös siihen miten toiset heitä määrittelevät.

Koska lainsäädäntö on muuttunut useaan otteeseen, ovat paluumuuttajia koskevat vaatimukset vaihdelleet eri aikoina. Jo pelkästään virallisen määritelmän mukaan on olemassa erilaisia paluumuuttajuuksia. Lainsäädäntö mahdollistaa paluumuuton, mutta jokaisen ratkaisu muuttaa Suomeen on henkilökohtainen. Siksi ei ole yhtä oikeaa paluumuuttaja- tai paluumuuttoselitystä. Anna oli muuttaessaan inkerinsuo- 
malaisten alaikäinen lapsi, joka pääsi muuttamaan vanhempiensa mukana. Hänen vanhempansa ovat luultavasti käyneet paluumuuttovalmennuksen, vaikka Anna ei paluumuuttoprosessia muistakaan. Paluumuuttoprosessi ei hänen kertomuksessaan ole merkityksellinen, vaan merkitykselliseksi nousee nimenomaan Suomeen muuttoa seurannut kotoutumisen ja kasvun aika. Elsa puolestaan on kuulunut siirtoväkeen ja on kansallisuudeltaan suomalainen.

Annikki Kaivola-Bregenhøj on kirjoittanut Inkerissä tekemiensä inkerinsuomalaisten haastattelujen pohjalta yhdestä haastateltavastaan, joka asetti sodan elämäntarinansa kulmakiveksi. Elämästään kertovat aloittivat yleensä lapsuusmuistoillaan jatkaen tarinaa käännekohtiin. (Kaivola-Bregenhøj 2006, 5.) Neuvostovaltaa seuranneet karkotukset, vainot sekä sota ovat kulmakiviä Elsan kerronnassa, kuten myös muiden haastattelemieni Inkerinmaalla syntyneiden kerronnassa. Kotiseudulta pois joutuminen sekä eroaminen läheisistä ovat traumaattisia tapahtumia, varsinkin kun haastateltavat ovat olleet lapsia niiden tapahtuessa. Omaa itseä kuvataan näiden tapahtumien kautta. Ne ovat johtaneet siihen, että elämä on ollut niin kuin se on ollut. Elsallakin tie vei Petroskoihin, koska se oli paikka, joka hänen sanojensa mukaan "otti vastaan".

Nuorelle Annalle inkerinsuomalaisten kärsimyshistoria on nimenomaan historiaa, jota hän ei ole kokenut. Suvun historia on hänenkin kertomuksessaan kuitenkin läsnä. Annan kertomuksen käännekohta, paluumuutto- ja kasvukertomuksen alku, on kotikaupungista Pietarista pois joutuminen. Aluksi se merkitsi Annalle tragediaa. Kärsimyshistorian etäisyys voi olla yksi syy, miksi hän voi kutsua itseään sekä suomalaiseksi, inkerinsuomalaiseksi että venäläiseksi.

Toisen selkeän kulmakiven paluumuuttajien haastatteluissa muodostaa muuttohetki Suomeen. Olin kertonut haastateltavilleni tutkivani nimenomaan paluumuuttoa. Nuorta polvea edustava Anna keskittyikin kertomaan Suomeen muutostaan ja Suomessa asumisestaan. Onhan se ollut hänelle toki puolet elämästä ja aikuiseksi kasvamisen aika. Elsa kuitenkin kertoi enemmänkin paluumuutosta vain osana koko elämäänsä. Varhaisemmat tapahtumat olivat muodostuneet hänen mielessään kertomuksiksi, joita hän kertoi mielellään. Suomeen muutto oli hänelle nykyisyyttä, jota nuo menneisyyden tarinat taustoittivat.

Paluumuuttajahaastateltavani ovat kertoneet syistään Suomeen muuttoon. Anna muutti, koska hänen vanhempansa muuttivat. Hän ei kuitenkaan muuttanut takaisin Pietariin, kuten hän aluksi ajatteli, vaan löysi oman tulevaisuutensa Suomesta. Elsa sen sijaan kertoi muuttaneensa, koska hänen lapsensa ja lapsenlapsensa asuivat jo Suomessa. Hänen poikansa oli muuttanut kaksikymmentä vuotta aiemmin töiden perässä. Töissä käyminen olikin seikka, jota Elsa lastensa ja lastenlastensa kohdalla erityisesti painotti. Elsa itsekin oli ollut jo aiemmin paluumuuttojonossa, mutta ei ollut halunnut muuttaa Suomeen niin kauan kuin hänen iäkäs isänsä oli elossa.

Isä meni toiseen maailmaan, satayksi vuosi oli. Minä hoisin häntä Petroskoissa. Minä, voip olla voisin ennen tullut suomeen asumaan. Sen vuoksi kaksi kertaa jono oli ja minä en mennyt sen vuoksi että isä oli vanha. Ja en minä isää tänne Suomeen käynyt tuomaan.

Paluumuuttokerronta pitää sisällään muutosta rakentuneita merkityksiä. Esiin nou- 
sevia teemoja ovat esimerkiksi tuttuus ja vieraus. Annalle vierautta edustaa Suomeen muuton aiheuttama tulevaisuuden suunnitelmien muuttuminen ja tuttuutta suomalainen tapa viettää joulua tai luterilaisuus ylipäänsä. Suomalaisuuden ja venäläisyyden analysoiminen omassa itsessä on monesti tullut haastatteluissa esiin ennen kuin olen asiasta mitään kysynyt. Haastattelun tekohetkellä monen haastateltavan niin sanottu kotoutumisprosessi on kuitenkin ollut kesken. Suomeen muutto ja kotoutuminen ovat kertomuksissa läsnä olevaa aikaa. Kesken on ollut myös tarinankehittymisprosessi.

Kerrottu paluumuutto pitää sisällään siis esimerkiksi merkityksiä, käännekohtia ja määrityksiä. Kerrontaa kuuntelemalla voidaan tavoittaa niin sanottua toista tietoa (ks. Hänninen, Karjalainen \& Lahti 2005, 3-6; Fingerroos \& Haanpää 2009, 135-136; Fingerroos \& Peltonen 2006, 11-13). Tämä toinen tieto tuo erilaisia näkökulmia virallisen tiedon oheen, tuoden vastapainoa tai täydennystä sille. Sakari Hännisen, Jouko Karjalaisen ja Tuukka Lahden toimittamassa teoksessa Toinen tieto - Kirjoituksia buono-osaisuuden tunnistamisesta (2005) on todettu virallisen tiedon olevan "pikemminkin yleiskatsauksellista kuin yksityiskohtaista, konstruoitua pikemmin kuin kokemuksellista, poikkileikkauksellista pikemmin kuin pitkittäistä, ilmeistä pikemmin kuin ihmettelevää”. Virallinen tieto pyrkii esittämään julkisen totuuden asiasta heijastaen sitä, mitä viralliset instituutiot ajattelevat. Toisella tiedolla sen sijaan viitataan mahdollisimman yksityiskohtaiseen, kokemukselliseen, paikantuneeseen, ihmettelevään, paljastavaan ja pohdiskelevaan tietoon. (Hänninen, Karjalainen \& Lahti 2005, 4.)

Toinen tieto on tietoa, joka on kertojalle tärkeää. Se on tietoa, jota muistitietoaineistot kuten haastattelut voivat tuoda esiin. Toinen tieto on kokemuksellista ja kokijalähtöistä tietoa. Anna ja Elsa ovat kertoneet paluumuutostaan minulle - tutkijalle - tiedostaen, että tulen käyttämään heidän kertomaansa tutkimukseni aineistona.

Käytännön maahanmuuttajatyöhön kerrottu paluumuutto voisi tarjota tietoa esimerkiksi siitä, miten yksilöt kokevat maahanmuuton tapahtuneen. Tällaista paluumuuttokertomuksien merkityksellistä toista tietoa ovat esimerkiksi sopeutumiskertomukset. Ne pitävät sisällään yksilöllisiä selviytymiskeinoja. Esimerkiksi Annan puhe sopeutumisestaan oli hyvin rehellistä. Hän ei vähätellyt ongelmiaan. Toisaalta lopputulos oli oletusarvoisesti hyvä, sillä Anna oli löytänyt oman paikkansa Suomessa. Hänellä oli haastattelukokemusta niin haastateltavana, kuin haastattelijanakin. Annan puhe sisälsi kokemuksia, näkemyksiä - paljon aineksia toisen tiedon hyödyntämiseen.

\section{VIITTEET}

1 Olen kerännyt aineistot ja kirjoittanut tämän artikkelin työskennellessäni tohtorikoulutettavan Suomen akatemian rahoittamassa tutkimushankkeessa Strangers from the East - Narratives of Karelian Exiles and Re-immigrants from Russia Regarding their Integration in Finland (2008-2012, johtaja Outi Fingerroos, projektinumero 128401).

2 Maahanmuutovirasto on esimerkiksi Asettamispäätöksessään SM088:00/2009 käyttänyt lukua 30000 . 
3 Savakot olivat lähtöisin pääasiassa Savosta ja äyrämöiset Karjalan kannakselta. Heidät erotti alueen alkuperäisistä asukkaista, vatjoista ja inkerikoista, esimerkiksi se, että he olivat luterilaisia.

4 Vuodesta 2004 vuoteen 2011 oleskelupa on annettu Neuvostoliiton alueelta peräisin olevalle henkilölle: "1) jos hakija on kuulunut Inkerin siirtoväkeen, joka vuosina 1943 ja 1944 siirrettiin Suomeen ja sodan päätyttyä palautettiin Neuvostoliittoon; 2) jos hakija on palvellut suomen armeijassa vuosien 1939-1945 aikana, tai 3) jos hakija itse, toinen hänen vanhemmistaan tai ainakin kaksi hänen neljästä isovanhemmastaan on tai on ollut merkittynä asiakirjaan kansallisuudeltaan suomalaiseksi ja hakijalla on riittävä suomen tai ruotsin kielen taito.” (Ulkomaalaislaki 30.4.2004/301, 48ฐ.)

5 Inkerin suomalaiset ja Suomen suomalaiset elivät vuosikymmenten ajan erityksissä toisistaan. Tänä aikana molempien kulttuuri ja kulttuuriperintö olivat eläneet elämäänsä erilaisissa ympäristöissä ja vuorovaikutuksissa. Pian paluumuuton alettua alkoi jopa liikkua huhuja ei oikeista inkeriläisistä ja lehdistössäkin puhuttiin "valeinkeriläisistä" (ks. esim. Leizinger 2010, 83).

\section{LÄHTEET}

\section{Tutkimusaineistot}

Haastattelut:

Paluumuuttajien haastattelut vuosina 2010-2011. Satakunta. Haastattelija Minna-Liisa Salonsaari. Nauhoitteet ja litteraatiot ovat tekijän hallussa. Haastateltavat:

- Elsa: Haastattelu tehty Porissa 28.5.2010.

— Anna: Haastattelu tehty Porissa 25.5.2010.

Lainsäädäntö:

— Ulkomaalaislaki 22.2.1991/378, 18a \.

- Laki ulkomaalaislain muuttamisesta 511/1996, 18a \.

- Laki ulkomaalaislain muuttamisesta 218/2003, 18a \$.

— Ulkomaalaislaki 30.4.2004/301, 48 \$.

— Laki ulkomaalaislain 48 §:n muuttamisesta 57/2011.

— Laki kotoutumisen edistämisestä 1386/2010.

Tilastot:

Paluumuutto entisen Neuvostoliiton alueelta vuosina 1998-1999. Työ- ja elinkeinotoimisto [online]. <http://www.mol.fi/mol/fi/99_pdf/fi/04_maahanmuutto/08_maahanmuuttotilastot/pal993.pdf $>$ [24.2.2012.]

Paluumuutto entisen Neuvostoliiton alueelta vuosina 2000-2007. Työ- ja elinkeinotoimisto [online] <http://www.intermin.fi/intermin/images.nsf/files/f15d5157 648fe1ccc22573d80031be4c/\$file/pal073.pdf> [24.2.2012.] 
Minna-Liisa Salonsaari: Kerrottu ja muisteltu inkerinsuomalaisten paluumuutto

Suomen virallinen tilasto (SVT). Väestörakenne [online]. Helsinki: Tilastokeskus. $<$ http://www.stat.fi/til/vaerak/index.html> [24.2.2012.]

\section{Kirjallisuus}

FINGERROOS, OUTI \& HAANPÄÄ, RIINA 2009: Vieraita idästä. Siirtokarjalaisten ja venäläisten paluumuuttajien kotoutuminen Suomeen. - Ruotsala, Helena \& Saarikoski, Petri \& Santikko, Maija (toim.), Matkalla. Pori: Kulttuurituotannon ja maisemantutkimuksen laitos.

FINGERROOS, OUTI \& PELTONEN, ULLA-MAIJA 2006: Muistitieto ja tutkimus. - Fingerroos, Outi \& Haanpää, Riina \& Heimo, Anne \& Peltonen, UllaMaija (toim.), Muistitietotutkimus. Metodologisia kysymykesiä. Helsinki: Suomalaisen Kirjallisuuden Seura.

HEIKKINEN, KAIJA 2003: Nationalistinen karelianismi paluumuuttajien kiusana. - Simonen, Raisa \& Heikkinen, Kaija (toim.), Monenkirjava rasismi. Joensuu: Joensuu University Press.

HYVÄRINEN, MATTI 2006: Kerronnallinen tutkimus [online]. <www.hyvarinen.info> HÄNNINEN, VILMA 1999: Sisäinen tarina, elämä ja muntos. Tampere: Tampereen yliopisto.

HÄNNINEN, SAKARI \& KARJALAINEN, JOUKO \& LAHTI, TUUKKA (toim.) 2005: Toinen tieto. Kirjoituksia buono-osaisunden tunnistamisesta. Helsinki: Sosiaali- ja terveysalan tutkimus- ja kehittämiskeskus.

Inkerinsuomalaisten maahanmuntto Suomeen 1990-luvulla, 1998. Työministeri Liisa Jaakonsaaren Eduskunnan ulkoasianvaliokunnalle 9.12.1998 antama Suomen hallituksen selonteko inkeriläisten maahanmuutosta Suomeen 1990-luvulla. Työhallinnon julkaisu nro 215. Helsinki: Työministeriö.

KAIVOLA-BREGENHØJ, ANNIKKI 2006: War as a turning point in life. - Bregenhøj, Annikki \& Klein, Barbro \& Palmenfelt, Ulf (toim.), Narrating, doing, experiencing, Nordic Folkloristic Perspectives. Helsinki: Suomalaisen Kirjallisuuden Seura.

LEIZINGER, ANTERO (toim.) 2010: Mansikkamaan vartijat. Muistelmia ulkomaalaisballinosta eri vuosikymmeniltä. Helsinki: Maahanmuuttovirasto.

MAKKONEN, ELINA 2009: Muistitiedon etnografiaa tuottamassa. Joensuu: Joensuun yliopisto.

NEVALAINEN, PEKKA \& SIHVO, HANNES (toim.) 1992: Inkeri-Historia, kansa, kulttuuri. Helsinki: Suomalaisen Kirjallisuuden Seura.

Porin kaupungin Maabanmunttajien kotouttamisohjelma, 2000. Pori: Porin kaupunki.

PORTELLI, ALESSANDRO 2006: Mikä tekee muistitietotutkimuksesta erityisen? - Fingerroos, Outi \& Haanpää, Riina \& Heimo, Anne \& Peltonen, Ulla-Maija (toim.), Muistitietotutkimus. Metodologisia kysymyksiä. Helsinki: Suomalaisen Kirjallisuuden Seura.

TAKALO, PIRJO \& JUOTE, MARI 1995: Inkerinsuomalaiset. Helsinki: Sosiaali- ja terveysministeriö, Pakolaistoimisto.

UKKONEN, TAINA 2000: Menneisyyden tulkinta kertomalla. Muistelupube oman historian 
Minna-Liisa Salonsaari: Kerrottu ja muisteltu inkerinsuomalaisten paluumuutto

ja kokemuskertomusten tuottamisprosessina. Helsinki: Suomalaisen Kirjallisuuden Seura. UKKONEN, TAINA 2007: Toivo paranemisesta: Nuoren naisen päihdetarinan rakentuminen haastattelussa. Elore 14(1) [online]. <http://www.elore.fi/arkisto/1_07/ukk1_07.pdf>

Tohtoriopiskelija Minna-Liisa Salonsaari valmistelee väitöskirjaa Turun yliopiston kulttuuriperinnön oppiaineessa. 